How to cite this article:

Murugasu, S. (2020). Democratizing local government: What Malaysia can learn from Mexico and India. Journal of International Studies, 16, 183-194. https://doi.org/10.32890/jis2020.16.11

\title{
Democratizing Local Government: What Malaysia Can Learn from Mexico and India
}

\author{
Sheila Murugasu \\ School of International Studies, \\ Universiti Utara Malaysia, Malaysia \\ sheila@uum.edu.my
}

Received: $1 / 1 / 2020$

Revised: 27/9/2020

Accepted: 15/11/2020

Published: 30/12/2020

\begin{abstract}
The Pakatan Harapan 2018 election manifesto had established commitments to strengthen the authority of local government, and to make local councils more accountable. This suggested that the local government elections would resume, after an absence of more than 60 years. While the Pakatan Harapan's tenure as Malaysia's ruling government was shortlived, their rise to power did put the local government back into the spotlight, as well as elevated the prospects of the resumption of local government elections in the country. There are a number of reasons that supports a more democratic and participatory approach to local government which has been highly hoped for in Malaysia. These include the view that it discourages public malfeasance and produces local officials that are more responsive to the needs of the citizens they serve. However, there are challenges that follow with the introduction of a more democratic form of local government, especially for countries that are attempting to transition from authoritarianism to a democracy at the national level, and contain a diverse multi-ethnic population of differing socio-economic backgrounds.
\end{abstract}

In order to better understand what these challenges are and how they can be overcome, this study examines two case studies, Mexico and India. These two countries have shown some similarities to Malaysia, particularly with regards to regime-type and demographics. This study considers the evolving approach taken by these two countries on their local government, in terms of their structure and practices. It is proposed that the case studies could provide potential lessons for Malaysia. This study begins with a brief historical overview of the system of local government in Malaysia to present day. This is followed by a discussion of the uneven experiences of Mexico and India on the efforts to democratize their local governments. The findings from the examination of both the case studies reveal the manner for which the countries with an authoritarian past often undergo during a 
transitional period, whereby although the structures of local governance have become more democratic, local officials and citizens are remain trapped in the old authoritarian modes of behavior. Unless interventionist steps are taken, democratizing local government structures alone do not necessarily lead to greater citizen empowerment, especially for those from the more marginalized sections of society.

Keywords: Local government, democracy, elections, Malaysia, India, Mexico.

\section{Introduction}

Malaysia's form of local government has its roots in the past as a former British colony. The first local authorities were established in the $19^{\text {th }}$ century, in what was then referred to as the Straits Settlement (now Penang, Melaka and Singapore), and was later extended to the other Malayan states. Local government elections were carried out after World War Two. In anticipation of independence, new local authorities sprouted throughout British-controlled Malaya. By 1957, there were a total of 289 local authorities within the country, with council officials elected through local municipal elections (Harding, 2012). However, in 1965, the federal government had ended the local elections. Initially, it was only meant to be a temporary emergency measure when the government was dealing with the 'konfrontasi' with Indonesia. Nevertheless, till today, local government elections have yet to resume in Malaysia. The reasons behind this decision, as suggested by the successive governments include the potential for local elections to disrupt the social harmony among the various ethnic groups in the country, the need to prioritize development above all else including becoming more democratic, and the belief that elections at the federal and state levels were sufficient to capture the wishes of the people (Phang, 2011). ${ }^{1}$

In 1968, a royal commission on local authorities released a report (the 'Nahappen' Report), whereby the report had recommended the resumption of local government elections, but with a fewer number of local authorities (Harding, 2012). Their recommendation however, was ignored. Another report was issued in 1971 by a unit from within the Prime Minister's department, in which the idea of holding local government elections was rejected on grounds that it would lead to an "over-democratization" of local government. This report would eventually overrule the 'Nahappen' Report (Harding, 2012; Savaranamuttu, 2000). The aftermath of these maneuvers in the 1960s and 70s by previous regimes had subsequently weaken the power and authority of local governments in Malaysia (Tennant, 1973).

The primary provisions in the legislation that incorporate local governments in Malaysia is the Local Government Act 1976. As of 2014, there were a total of 149 local authorities. This included 12 city councils, 39 municipal councils, 98 district councils, and five special and modified local authorities (Penang Monthly, 2018). Local council members and the mayor/chairperson are appointed by the state government, and are usually party loyalists or

However, sceptics believe the real concern may have more to do with maintaining the political hegemony of the ruling elite. 
'prominent citizens' who resided in the area. The remit of local councils includes housing and town planning, maintenance of roads, parks and other public places, as well as refuse collection and disposal. Local councils derive their revenue from rents, fees, licenses, and through property taxes. They also receive state and federal grants. However, it is apparent that the total revenue generated, which includes state and federal grants, are often not enough to cover the operational costs of most councils. Therefore, many local governments resort to borrowing from either the state or federal governments.

Although the provisions on local governments are envisaged under the federal constitution, local government is a state matter. As noted by Phang (2011, p.158), the federal government, through an entity known as the National Council for Local Government (NCLG), "can exert influence to ensure that state and local authorities follow national policies". Phang (2011, p.160) further asserted that "under the provision of the federal constitution Article 95 (A), the decisions of the NCLG are binding on all state governments". Another indication of the federal government's decision-making power over local government is the fact that the NCLG members include the deputy prime minister, state chief ministers, the minister of housing and local government, as well officials from a number of federal ministries. Noticeably absent from the council are the council presidents, mayors and district chiefs.

Given their importance in public life, it is unfortunate that most Malaysians are not aware of the responsibilities of the local government bodies. There is an almost complete disconnect between local government and the constituent it serves. It is not inconceivable for a resident to have never visited or met with a local government official, or councilor that represents their residential area, and are unaware of any council meetings that are open to the public. Other issues that relate to local governments in Malaysia also includes the centralization of planning with very little input solicited at the local levels, even when many of the problems and issues are local in nature and different for each community. As stated by Phang (2011), in Malaysia, the trend since the 1970s has been to move towards recentralization, rather than the decentralization of power of the local governments.

Following the 2018 general election, in which the Pakatan Harapan (PH) won, it seemed as though there might be a reversal of policy. This was in light of the commitment to local government elections made by the Pakatan Harapan in its manifesto. Indeed, one of the first things the then newly appointed Minister of Housing and Local Government, Zuraida Kamaruddin, signaled when she assumed her position was her ministry's intention to reintroduce local government elections by 2020 (Kow, 2019) ${ }^{2}$. She further indicated that local elections would most likely be commenced in stages, with Penang likely used as a test case before a nationwide approval for the local government election (Bernama, 2019). Despite the fact that the reinstatement of local government elections was part of the $\mathrm{PH}$ manifesto, and that the minister with oversight over local government matters was clearly enthused with the idea, PH Prime Minister Mahathir Mohammad in the latter part of 2018,

2 Zuraida Kamaruddin remains Minister of Housing and Local Government, but she now holds that portfolio as part of the Perikatan Nasional (PN) government. The PN government came into power in March 2020, after several members of parliament broke away from $\mathrm{PH}$ and aligned themselves with factions from the old ruling coalition, Barisan Nasional, to form a new coalition. 
had dismissed the plan outright as he believed that the local elections would produce [the] 'wrong results', and would further divide the urban and rural areas (Rajvinder, 2018). Meanwhile, the new ruling coalition that came into power in March of 2020, Perikatan Nasional, had shown no interest to revive local elections either.

One of the questions that arise is; if there is no major discontentment among citizens with the status quo, why move towards democratizing local government and encourage greater political participation of citizens? To answer this question, it is important to examine the foreword to the UNDP Human Development Report of 1993, a report that was themed; People's Participation. The report states that (1993, p.65): "Democracy is more than drawing up constitutions, designing new election procedures or holding elections as one-time events. Democracy is a way of life". The report further states that the "people everywhere want to determine their own destiny. And the kind of democracy they choose need not follow the models of Western Europe or North America - it usually has to be adapted to local circumstances. But the formal structure a country opts for, whatever it is, is only the starting point in a long process of facilitating effective forms of popular participation."

Therefore, if one accepts this premise, where should Malaysia turn to for lessons if it wishes to embark on its own journey towards making its own local government system more democratic? It is proposed that Malaysia should analyze the decisions made by the countries that have undergone a similar transition, from a highly centralized government to one that is more devolved and democratic at all levels of government, and those that have implemented local government elections. Countries with a similar socio-economic profile should be considered, such as countries that have industrializing economies that are faced with issues that stemmed from having a multi-ethnic population, income inequality and weak democratic institutions due to an authoritarian past. With these factors in mind, Mexico and India were chosen as case studies for this paper, while the research method employed is comparative case study approach. As highlighted by Bennett and Elman (2007, p.171), the case study is particularly adept at "studying complex and relatively unstructured and infrequent phenomena."

The following section provides a brief overview of the nature of local government of these two countries.

\section{The Democratization of Local Government in Mexico: Dealing with the Leftover Legacy of Authoritarian Rule in Mexico}

During the greater part of the $20^{\text {th }}$ century, Mexico was essentially a one-party state that was ruled by the National Revolutionary Party, now known as the Institutional Revolutionary Party (PRI), since 1929. As an electoral authoritarian regime, Mexico had carried out periodic elections, but the dominance of the Revolutionary Party in these election were never in doubt due to the institutional arrangements that were designed to favour it. Eventually, political change did come to Mexico in the 1970s, with the introduction of a proportional representation electoral system. This led to more minority parties being represented in the legislature. In the 1990s, two new political parties were established, and had challenged PRI's stranglehold over the elections (Felbab-Brown, 2019). 
These changes subsequently culminated with the introduction of Vincente Fox in 2000. He made history by becoming Mexico's first president to be elected from the opposition party. The increased democratization at the national level in Mexico subsequently led to further democratization and decentralization of government at the state and local levels as well. This overview of events took place between 1980 and 2005, and was gradual. Grindle (2009, p.18) highlighted that "national administrations shifted emphases back and forth between commitment to decentralize and efforts to recentralize power in the national executive and were reluctant to threaten the capacity of PRI [the ruling party] to continue to win elections."

With regards to state and municipal governments, Grindle (2009, p.18) stated that by 2005 , Mexico "had more authority and resources to deal with regional and local issues than at any time in the country's history; likewise citizens enjoyed much more democratic elections and more opportunities to participate I public decision making than had been true in the recent or distant past."

While Mexico practices a different type of politics than Malaysia, there are some parallels especially with regards to the authoritarian nature of the state and the concentration of power in the executive branch of the federal government. As many scholars have noted (Gomez \& Jomo, 1997; Case, 2009), Malaysia's political system post-independence had exhibited features that were reflective of an authoritarian state. This included an increasing degradation to the checks and balances between the three branches of government through a series of amendments to Malaysia's constitution over the years that had greatly enhanced the Prime Minister's executive powers. While Mexico has a presidential system, rather than a parliamentary system like Malaysia, the country has a history of an executive branch that was granted a great deal of power to its political system that had subsequently experienced a sudden break from a long period of the one-party rule.

As such, there are lessons that could potentially be learnt from Mexico's attempts to democratize its own local government. The primary law that incorporated the provisions on local governments in Mexico is Article 115 of the constitution, which was passed in 1917. Amendments were made in the 1980s and 1990s that granted municipalities "greater budgeting and spending autonomy". Their responsibilities included local public works, parks and local public amenities, conflict management over property disputes but is dependent on the state and municipality which could be extended in partnership with the state, provisions on education, emergency fire and medical services, as well as environmental protection and preserving historical landmarks in the area. Mayors and councilors are usually elected through the party list system (Felbab-Brown, 2019).

Grindle (2009) conducted a study of Mexico's local government structure in 2004 across 30 different municipalities throughout the country that led to several pertinent findings. One of the findings was that there was a noticeable increase in political competitiveness at the local level, with new parties competing for council seats or for the position of Mayor. This gave voters more options to choose from. However, the added competition did not always translate to more accountability or responsiveness from the local officials. Grindle (2009) 
asserted that this is because citizens were not using their new found democratic powers to hold officials accountable.

The second finding from the study indicated that there was also more pluralism in local councils, particularly with regards to party representation. However, it was difficult to examine the direct correlation between greater pluralism and better governance. Grindle (2009) further noted that elected officials who tried to resolve local level problems were routinely stymied by insufficient funds, and were then forced to engage in often timeconsuming lobbying for more funds and resources from the state government officials. Local government were also often reluctant to levy additional taxes, even when they were given the powers to do so due to fear of a public backlash.

Additionally, although Mexico had become democratic in terms of its electoral process, relationship between party officials and bureaucrats were often premised on the "old ways", which were ways that were personalized and transactional in nature. Grindle (2009, p.20) stated that "to do a good job, local officials had to spend a great deal of time out of their offices, seeking support at state and national levels. Their success was often transitory however, as the weak local institutions that contributed to their extensive scope for action exposed their reforms to the short lives of each administration. Political traditions die hard even in contexts in which the structure of the authority had moved from authoritarian to democratic."

Gomez (2019, p.2), in a commentary piece for the New Mandala, highlighted a similar dilemma of having to deal with political traditions that remain very much alive, even in the so-called "New Malaysia". The term was coined after the Pakatan Harapan won the 2018 general election. Despite Pakatan's promise of a new approach to reshape Malaysia's political economy, experience thus far suggests a surprising degree of continuity. Rather than giving up an appealing effective lever for consolidating power, Pakatan leaders seemed inclined to employ the same measures that were carried out by Barisan National. The 'tools' in question refers to PH's control over state agencies and resources, and their instrumental use to engage in patronage politics. Such measures were already apparent at the national level to consolidate power. This does not provide any justification as to how this may affect any future attempts for democratization at the local levels. Malaysia's local officials, quite possibly are considered somewhat similar to Mexican officials, will have to navigate an entrenched political culture from previous regimes which is less about serving their constituency and more to do with protecting elite interests.

Another finding from Grindle's study relates to how citizens who are not familiar with democratic culture, respond to their new found freedoms and rights to engage politically in the system. Grindle (2009, p. 177) states that, "the ways in which citizens related to government continued to reflect the legacies of the past. [In local elections and meetings over resource allocation] citizens had good opportunities to organize and were even encouraged to do so by local government on many occasions. Nevertheless, as indicated above, the dominant form of interacting with government was to petition for relief and to extract resources rather than to make demands for the observance of rights. To some 
extent then, local problem solving remained embedded in the clientelist practices of the pre-democratic past."

Therefore, even if the rights to acquire and demand for greater accountability were made available to the citizens, they may not exercise their rights due to the lack of awareness or the preference to stick with the "old ways".

The absence of a democratic culture and appreciation of democratic values may similarly limit any efforts to resume local government elections in Malaysia. In a nationwide survey on public attitudes towards democracy in Malaysia, Welsh (1996, p.903) highlighted that ethnicity was the driving force behind the average Malaysian' political views, whereby the author stated that, "it is clear from the results that Malaysians apparently do not support a change in the character of the regime, confirming other analysts' suggestions that the 'semidemocratic' regime in Malaysia is likely to continue. Malaysian respondents overall support the undemocratic character of the regime. In particular, the fact that economic growth seems to have made little impact on promoting democratic views suggests that support for change is minimal".

More than 20 years later after that survey was conducted, have the political attitudes of the Malaysian electorate changed? The evidence may suggest so. A study conducted by Pietsch and Clark (2015) suggested that there is support for democratic principles among the majority of Malaysian voters (more than 58 percent of survey respondents), despite expressing a high level of dissatisfaction with the institutions of government. Even so, democratic culture is far from being embedded into the lives of the average Malaysian.

With regards to improving accountability of local officials, there were several recommendations that were put forward by Grindle (2009). This included voter education on the ways for which citizens could effectively demand and hold their locally elected officials accountable. Another recommendation was to allow officials to run for reelection [which at the time of her study was limited by law to one term, and lasted only three years]. By knowing that they had an opportunity to serve another term, this provided the necessary incentive for local leaders to improve their overall performance and to be responsive to the electorate. Moreover, Grindle (2009:180) asserted that, "more competitive elections allowed citizens to punish parties they believe had performed poorly. With time such mechanisms could encourage more of a "culture of accountability" at local levels."

Another problem that was identified is the sustainability of good governance practices. Grindle (2009, p.181) noted that, "although innovations might bring improvements to the performance of administration and services in town hall, there was no certainty that they would outlive the tenure of those who introduced them. The problem, then, was not change, but the durability of new ideas and systems that improved local government performance". The challenge that needs to be addressed is to institutionalize any change and innovations that would ensure they remain beyond the tenure of the elected officials that had introduced them. However, the new rules and laws may not be enough. Therefore, active and vigilant citizens are needed to ensure continuity over the long term. 
Other than that, Grindle (2009) also noted that the ecosystem in which local-level democracy thrives are in places of economic growth, and at the locations where younger residents raise their families rather than migrate to other cities and towns. The migration of citizens from a locality would inevitably lead to impoverished communities and poor performing local governments that are due in part to less tax revenue. Grindle (2009, p.182) stated the following; "Over the longer term, good governance cannot thrive in decentralized contexts that are in economic and social decline". The main difference between the local governments, in terms of performance, and public satisfaction comes down to leadership. Different leaders produce different results, and the ones that were more entrepreneurial in nature were more likely to succeed.

\section{The Democratization of Local Government in India: Democracy is More Than Just Local Elections}

India has much more in common with Malaysia, hence making it another ideal case study that could be used for comparison. As a former British colony, it is a federation whereby the political powers are shared between the central and state governments, with the states having their own legislature, cabinet and chief minister. It has a bicameral parliament, and is a multi-party system for which the Prime Minister is elected from the party that has won the most seats in the lower house of parliament. India, like Malaysia, also has to contend with inter-ethnic relations as it is a multi-ethnic, multi-religious country, with Hindus forming the majority of its citizens.

There are significant differences, not least of which is the sheer size of the country both in terms of population (more than 1.3 billion versus Malaysia's 32 million), and land mass. India also deals with significantly more challenges that relate to poverty, infrastructure, and delivery of basic services due largely to its geographical spread.

India has had a local government system in place since its independence in 1947. However, during the early post-war days, policy-making and disbursal of funds were centralized at either the federal or state levels, and local-level officials were all appointed. The amendments made to the constitution in 1989, specifically the 73rd and 74th amendments, had subsequently resulted to a greater decentralization and democratization of rural and urban local governments across the country. The changes that ensued from these constitutional amendments included the introduction of a three-tiered local government system with different remits and powers, party-based elections at the local levels, state grants awarded to local government authorities, power of taxation for local authorities and a participatory planning mechanism that involved the local residents (Commonwealth Local Government Handbook, 2018).

Given India's federated system, the nature and powers of local government varies tremendously from state to state. This can also be observed in its organizational structure in rural/urban areas, and constituency size. Thus, trying to draw definitive lessons that is suggested to be representative of India as a whole is virtually impossible. Instead, a more useful approach is to look at one particular state, namely the state of Kerala, which is 
located along the Malabar Coast in the southwest region of the country. As one of the most developed states in the country with a population of 33 million, the state government has made concerted efforts to democratize local governance since the 1990s. After the 1989 federal constitutional amendments, the state of Kerala also enacted its own state legislation, namely the Kerala Municipality Act 1994 and the Kerala Panchayat Raj Act 1994. These legislatures granted autonomy to local authorities on issues relating to budgets, taxation, and local planning by residents (Harilal, 2008).

Among the more significant takeaways from Kerala's political experience with local governance is the emphasis placed on democratization that is not only solely reliant on the locally-elected officials, but to also make public participation integral to every level of project planning and implementation at the local level. The state has made its 'from-theground-up' participatory planning mechanism to be a cornerstone of local governance in the state. As outlined by Harilal (2008) who conducted a study on the political system in Kerala from the late 1990 s to 2002 , the mechanism involved were comprised of five main stages. The first is to identify the development needs and problems of the local area which are done through discussions in the village assembly, where the members are representative of the community and takes into account gender, ethnicity, religion, tribe and caste, as well making the effort to draw in marginalized groups into these discussions.

These problems and needs are then presented during a development seminar at the municipal level, during which possible solutions are formulated to address them and involves local political leaders, technical experts and representatives from the various village assemblies that fall under the jurisdiction of the municipal authority in question. The three other subsequent phases in the planning process involve the selection of problems/issues to address (which is often resource-dependent), technical drafting and project development that also includes integrating local-level plans that could be developed into the bigger development schema of the state. The final stage is the actual implementation, followed by a monitoring and auditing processes.

At the time of Harilal's study of the state's local governance, Kerala had instituted its participatory planning mechanism for several years. The study was able to determine some of the strengths and weaknesses of the mechanism, particularly on the effectiveness of democratization towards decision-making. The findings of the study suggested an overall drop in public participation in the first and second phases of the participatory planning, as well as the fact that public participation was uneven from region to region. It was highlighted that people in the more urban areas were less likely to participate. It was proposed that this may be due to disinterest, and the fact that the more economically well-off residents tended to engage in rational choice deliberations when it came to deciding if it was worth their time and energy to involve themselves in the planning and discussion process, given that many of the identified problems did not affect them. Moreover, there was also the issue of being physically present, but not actually being vocal or influential during the actual decisionmaking process. Harilal $(2008$, p.83) indicated that this was often the case when it came to minorities and women who were present at such planning meetings, and argued that they "were not in a position to assert their views." 
Apart from the uneven levels of participation between the different genders and socioeconomic groups in local governance, Harilal (2008) highlighted other issues in the participatory planning mechanism that was adopted by Kerala. The issue pertains to the economies of scale (the lack of it), and the propensity in some cases on the plans of one local village that may have an unintended negative "downstream effect" on another neighbouring village. Although the various concerns on the decentralized nature of participatory planning were discussed, the solution proposed was not to return to centralized planning, but rather to revisit the architecture of decentralized planning to better integrate the various plans, and to establish clearer division of responsibility and powers of the different stakeholders. Furthermore, to recognize that there are certain local problems such as unemployment and poor economic growth that are externally driven rather than locally, a more coordinated policy response is required at the higher levels of government to resolve these problem.

\section{Conclusion}

In the opening of her book Going Local, Grindle (2009) highlighted the many changes to local governance, which began since the 1980 s and would continue well into the 2000 s. Of this period, she writes $(2009$, p.185):

"The quality of local governance became newly relevant to millions of people around the world in the early twenty-first century. Whereas municipal governments had long had some role in the management of local affairs, in the final decades of the twentieth century they were given many new responsibilities, provided with considerable more resources, and allowed greater autonomy than had been true in the past. In developing countries, these new powers stood in contrast to decades of centralized management of public affairs. Now, the decentralisation of fiscal, administrative, and political responsibilities challenged local governments to become more effective at carrying out the public's business and more democratic in their decisionmaking process".

However, these changes did not transpire in Malaysia, which has continued to implement its post-British political system from the past. Apart from a few relatively minor organisational changes over the years, Malaysia's system of local government has remained virtually unchanged since 1965, particularly on the matters that relate to federal-state relations and the devolution of power at the local levels.

Lim (2020), a former city councilor for the city of Georgetown, lamented the fact that while the Local Government Act of 1976 contains provisions that could encourage engagement between citizens and local officials, whether it be through meetings or feedback on development plans, it is rarely practiced. Lim $(2020$, p.10) further noted that, "there is no encouragement of genuine and meaningful public participation. What little public participation afforded is limited to formalities....there is a huge deficit in public participation, not to mention elections, in local government in Malaysia”. 
There are many reasons that would support the return of local elections in Malaysia. Among these reasons is the inherent right of citizens to exert their opinions and thoughts on the ways the communities in which they live and pay taxes are managed. Citizens should also have the opportunity to vote local officials out of power, should they be corrupt or fail to address the problems of the constituents they serve.

The experiences of local governments in Mexico and India indicate that institutionalizing democracy is dependent on having a thriving economic communities that have been embedded with a democratic culture at the local level. However, this takes time to develop. However, democratizing local government poses its own set of challenges and problems. Even for established democratic countries like the United States, voter turnout in local elections can be as low as ten percent (Bernstein, 2019). Other issues include managing public expectations on the responsibilities of the local governments, dealing with participation inertia on the part of local residents, as well as concerns of the entrenched elite on the significance of local elections to the balance of power in a country used by a dominant ruling party or a strong executive. These issues however, are certainly not unique to Malaysia. The advantages of ensuring a more democratic local government certainly outweigh the negatives.

\section{Acknowledgement}

This research received no specific grant from any funding agency in the public.

\section{References}

Ahmad A. H. (2002). Local Government: Theory and practice in Malaysia. Dewan Bahasa Pustaka.

Bellamy, R. (2008). Citizenship: A very short introduction. Oxford University Press.

Bennett, A., \& Elman, C. (2007). Case study methods in the international relations subfield. Comparative Political Studies, 40(2), 170-195. http://doi. org/10.1177/0010414006296346

Three years needed to prepare local council election's working paper. (2018, September 18). Bernama. http://www.bernama.com/en/news.php?id=1757932

Bernstein, J. (2019, April 29). Why no one votes in local elections. Bloomberg. https://www. bloomberg.com/opinion/articles/2019-04-29/why-no-one-votes-in-local-elections

Case, W. (2009). Electoral authoritarianism in Malaysia: Trajectory shift. The Pacific Review, 22(3), 311-333. https://doi.org/10.1080/09512740903068362

Commonwealth Local Government Handbook. (2018). The local government system in Malaysia. Commonwealth Local Government Forum. shorturl.at/vzB12

Commonwealth Local Government Handbook(2018Thelocalgovernmentsystemiia.

Commonwealth Local Government Forum. shorturl.at/ptxEV

Grindle, M. (2009). Going local: Decentralisation, democratization, and the promise of good governance. Princeton University Press. 
Gomez, E., \& Jomo K. S. (1997) Malaysia's political economy: Politics, patronage and profits. Cambridge University Press.

Gomez, E. (2019). Business as usual: Regime change and glcs in Malaysia. New Mandala. https://www.newmandala.org/business-as-usual-regime-change-and-glcs-inmalaysia/

Harding A. J. (2008). Government, democratic participation and the urban environment in peninsular Malaysia, Australian Journal of Asian Law, 10(1), 1-25.

Harilal, K. N. (2008). Redesigning local governance in India: Lessons from the Kerala experiement. In F.Saito (Ed.), Foundations for Local Governance (pp.75-92). Physica-Verlag.

Hemananthani, S., Carvalho, M., Rahimy, R., \& Tan, T. (2019, July 8). Raja Kamarul: Local government elections being studied, The Star Online. https:/www.thestar.com.my/ news/nation/2019/07/08/raja-kamarul-local-government-elections-being-studied

Felbab-Brown, V. (2019). The ills and cures of Mexico's democracy. Foreign Policy at Brookings Institute. shorturl.at/pGKMR

Kow, G. C. (2019, May 1). Govt' expected to amends laws to restore local elections in 2020, Malaysiakini. https://www.malaysiakini.com/news/474411

Lim, M. H. (2020). Local democracy denied? A personal journey into local government in Malaysia. Strategic Information and Research Development Centre.

Nuwer, R. (2018). Why governments are broken and how to fix them, BBC Future. https:// www.bbc.com/future/article/20180116-why-governments-are-broken-and-how-tofix-them.

Local Government in Malaysia: Types, Functions, Organisation, Members and Budget. (2018). Penang Monthly. Penang Institute. shorturl.at/gyF38

Phang, S. N. (2011). Decentralization and Local Governance in Malaysia. In Berman, E. (Ed.), Public Administration in Southeast Asia (pp. 155-169). CRC Press.

Pietsch, J., \& Clark, M. (2015). Critical citizens: Attitudes towards democracy in Indonesia and Malaysia. Japanese Journal of Political Science, 16(02), 195-209. https://doi. org/10.1017/S1468109915000031

Rajvinder, S. (2018, December 10). Govt will not hold local govt elections, says Mahathir. The Sun Daily. https://www.thesundaily.my/local/govt-will-not-hold-local-govtelections-says-mahathir-DG239489.

Savaranamuttu, J. (2000). Act of betrayal: The snuffing out of local democracy in Malaysia, Aliran Monthly. https://aliran.com/archives/monthly/2000/04h.html

Tennant, P. (1973). The decline of elective local government in Malaysia. Asian Survey, 13(4), 347-365.

United Nations Development Programme. (1993). Human Development Report. Oxford University Press. shorturl.at/itwIP

Welsh, B. (1996). Attitudes toward democracy in Malaysia: Challenges to the regime? Asian Survey, 36(9), 882-903. https://doi.org/10.2307/2645537 